University of Louisville

ThinkIR: The University of Louisville's Institutional Repository

Electronic Theses and Dissertations

$12-2003$

\title{
The problem of religious diversity : a study and critique of the philosophy of John Hick.
}

John K. Dryden 1976-

University of Louisville

Follow this and additional works at: https://ir.library.louisville.edu/etd

\section{Recommended Citation}

Dryden, John K. 1976-, "The problem of religious diversity : a study and critique of the philosophy of John Hick." (2003). Electronic Theses and Dissertations. Paper 374.

https://doi.org/10.18297/etd/374

This Master's Thesis is brought to you for free and open access by ThinkIR: The University of Louisville's Institutional Repository. It has been accepted for inclusion in Electronic Theses and Dissertations by an authorized administrator of ThinkIR: The University of Louisville's Institutional Repository. This title appears here courtesy of the author, who has retained all other copyrights. For more information, please contact thinkir@louisville.edu. 


\title{
THE PROBLEM OF RELIGIOUS DIVERSITY: A STUDY AND CRITQUE OF
} THE PHILOSOPHY OF JOHN HICK

\author{
By \\ John K. Dryden, Jr. \\ B.A., University of Louisville, 2000
}

\begin{abstract}
A Thesis
Submitted to the Faculty of the

Graduate School of the University of Louisville

In Partial Fulfillment of the Requirements

for the Degree of
\end{abstract}

Master of Arts

Department of Humanities

University of Louisville

Louisville, Kentucky

December 2003 
THE PROBLEM OF RELIGIOUS DIVERSITY: A STUDY AND CRITIQUE OF THE PHILOSOPHY OF JOHN HICK

\author{
By \\ John K. Dryden, Jr. \\ B.A., University of Louisville, 2000
}

A Thesis Approved on

October 28, 2003

By the following Thesis Committee:

Thesis Director 


\section{DEDICATION}

This thesis is dedicated to my parents

Mr. John K. Dryden, Sr.

and

Mrs. Janet Dryden.

They never failed to give me the support, guidance, and encouragement I needed along the way. 


\section{ACKNOWLEDGMENTS}

I would like to thank Dr. Wiggins, my thesis director, for his unending patience in reading and commenting upon the countless drafts of the thesis. He proved terrific in encouraging me to think and rethink about the issues in order to improve my work. I also would like to thank Dr. Mary Ann Stenger for introducing me to the work of John Hick and for reading and commenting upon my rough draft. Finally, I would like to thank my fiancé, Julie Conway, for her patience and my family (Mom, Dad, Jessica, Jason, Noah, and Molly); I can never thank you all enough. 


\begin{abstract}
THE PROBLEM OF RELIGIOUS DIVERSITY:

A STUDY AND CRITIQUE OF THE PHILOSOPHY OF JOHN HICK
\end{abstract}

\author{
John K. Dryden, Jr. \\ Director: Osborne P. Wiggins
}

July 31,2003

This thesis is a study and critique of John Hick's pluralistic hypothesis as presented in his book An Interpretation of Religion. I primarily focus on two issues: Hick's epistemology of religious beliefs and the pluralistic hypothesis itself. These are two separate issues, but for Hick they prove to be inextricably linked. Hick uses his epistemological stance to argue that there is an epistemological problem of religious diversity. After he argues that there is a problem, he presents his solution, i.e. the pluralistic hypothesis. After explaining these issues, my critique focuses upon the connection between the two. I first critique Hick's epistemological stance and in so doing argue that his hypothesis is unwarranted. I then argue that even if Hick's epistemological position is correct, the problem of religious diversity is much broader than Hick presents it and his hypothesis is much too limited in scope to adequately deal with the problem. 
TABLE OF CONTENTS

PAGE

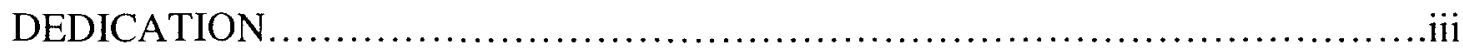

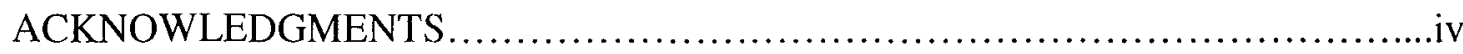

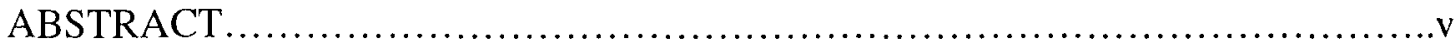

\section{CHAPTER}

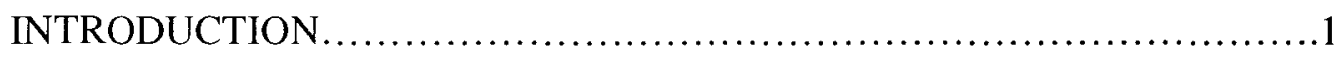

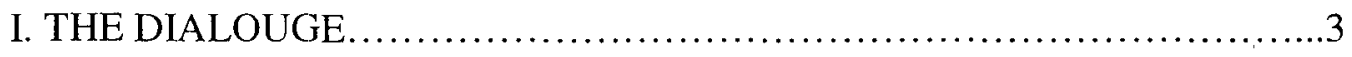

II. EXPLANATION OF HICK"S PLURALISTIC HYPOTHESIS..............14

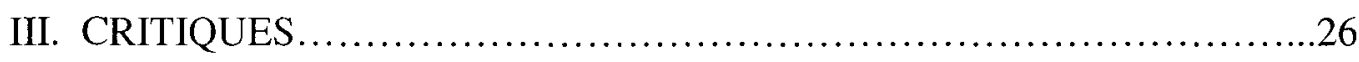

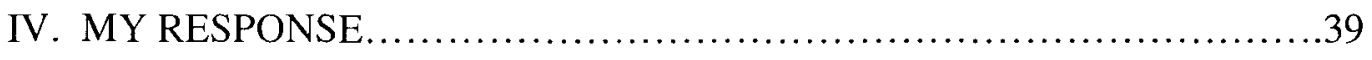

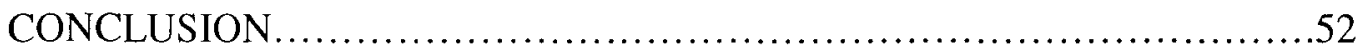

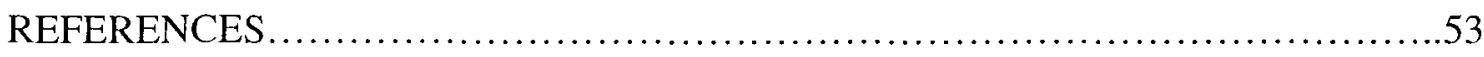

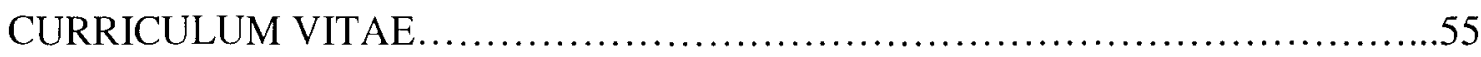




\section{Introduction}

Currently in the philosophy of religion, a debate over the problem of religious plurality continues among many philosophers. John Hick, a leading philosopher of religion who deals with this issue, cites the problem in the following way:

... the most viable defence of religious belief has to be a defence of the rationality of basing beliefs ... on religious experience. From the point of view of a Christian philosopher - as distinguished from a philosopher simply as such - there is, however, an obvious challenge to this in the fact that the same epistemological principle establishes the rationality of Jews, Muslims, Hindus, Buddhists etc. in holding beliefs that are at least partly, and sometimes quite radically, incompatible with the Christian beliefsystem. ${ }^{1}$

According to Hick, the traditional Christian assumption that Christianity is the 'one true religion' undermines Christian philosophers' efforts to rationalize religious belief by grounding it in religious experience. For "... if only one of the many belief-systems based upon religious experience can be true, it follows that religious experience generally produces false beliefs, and that it is thus a generally unreliable basis for belief formation." We shall see that Hick argues that you can either hold the view that there is only one true religion, or the view that that religious experience justifies religious beliefs, but not both, for these are contradictory positions.

\footnotetext{
${ }^{1}$ John Hick, Dialogues in the Philosophy of Religion (New York: Palgrave, 2001) 25.

${ }^{2}$ Hick, Dialogues in the Philosophy of Religion 26.
} 
The purpose of this paper is to fully explicate and take a stance on the debate of religious pluralism. I will do this by using the works of Hick, primarily An Interpretation of Religion, as my focal and entry point into the debate. In explicating the views of Hick, I will concentrate on two issues which for Hick are inextricably linked. The first issue concerns the justification of religious beliefs based upon religious experience; the second is Hick's pluralistic hypothesis. These are certainly two separate issues, but for Hick, the first gives rise to the second. Hick basically claims that the fact that religious beliefs are justified by religious experience creates a problem, the problem of religious diversity. Hick's solution to this problem is his pluralistic hypothesis.

After explaining Hick's position on the issue of the rationality of religious beliefs and his pluralistic hypothesis, I will then present critiques of Hick's work by other leading philosophers of religion. Last, I will reexamine the issue of the justification of religious beliefs and argue that Hick's pluralistic hypothesis is unwarranted. I will advocate the position of religious falliblism; that is, the position that religious beliefs are inherently uncertain and possibly mistaken. I will support Hick's claim that it is rational to trust our experience, even if it is religious experience, but argue that this does not lend itself to his version of pluralism. It does, however, suggest that religious beliefs (among other types of beliefs) should be accompanied with the realization that they could very well be mistaken. Moreover, this position of religious fallibilism will help us "move beyond the static situation of rival absolutisms."3

\footnotetext{
${ }^{3}$ John Hick, Disputed Questions in Theology and the Philosophy of Religion (New Haven: Yale UP, 1993) 154.
} 


\section{Chapter 1}

\section{The Dialogue: An Introduction to the Problem of Religious Diversity}

In Hick's book Dialogues in the Philosophy of Religion, is a dialogue between Hick and William Alston that nicely presents the problem of religious diversity. Before explaining this dialogue, let me first cover some basic presuppositions of Hick's argument for the problem of religious diversity. A central premise to Hick's argument is that the justification of religious belief must be grounded in religious experience. Hick distinguishes between two types of religious experience. 'In the one kind the 'information' is mediated through our material environment: things, events and processes in the world are experienced as having a religious character or meaning in virtue of which they manifest to us the presence of the transcendent". ${ }^{4}$ This first kind of religious experience is common both to the ordinary believer and to the great prophets and leaders of the various traditions. They occur in various forms and levels of intensity. This experience can take the form of "the sense. . . of one's life as being lived in the presence of God; the consciousness of ordinary life as avidya (illusion) and of all

\footnotetext{
${ }^{4}$ John Hick, An Interpretation of Religion (New Haven: Yale UP, 1989) 154.
} 
things as sunya (empty)". ${ }^{5}$ More generally it is "the whole experience of persons in so far as they are religious."

Distinguished from this type of religious experience is mystical experience, which Hick defines as:

those forms of religious experience that express the presence of the Real, not as manifested in our material environment, but as directly affecting the human psyche. These are experiences in which the 'information' being presented to consciousness has been received by some kind of extrasensory awareness of our ultimate environment. ${ }^{7}$

This mystical experience can take the form of the unitive experience of the oneness of God/Absolute etc. or the communitive experience of visions/auditions. $^{8}$

Hick's premise that religious beliefs are justified via these types of religious experience is critical to his argument for the problem of religious diversity and will prove central in the dialogue with Alston. Prior to Pascal, most philosophers tried to argue for the rationality of religious belief by making arguments for the existence of God. Pascal took a different approach, arguing that it is a greater risk not to believe in God than it is to believe in God. ${ }^{9}$ While Hick does not take this approach, he agrees with Pascal that "the justification of theistic belief does not consist in an argument moving directly to the conclusion that God exists but rather in an argument for the rationality of so believing despite the fact that this cannot be proved or shown to be in any objective sense

\footnotetext{
${ }^{5}$ Hick, An Interpretation of Religion 154.

${ }^{6}$ Hick, An Interpretation of Religion 154.

${ }^{7}$ Hick, An Interpretation of Religion 165.

${ }^{8}$ Hick, An Interpretation of Religion 165.

${ }^{9}$ Hick, An Interpretation of Religion 211.
} 
more probable than not." ${ }^{10}$ Natural theology and classical philosophy of religion has tried to show that theistic religious belief is rational by proving the existence of God. If God's existence could be proven, it would of course be rational to believe in God's existence. But this project has failed according to Hick, so he takes this alternative approach.

For Hick, the impossibility of proving the existence of God is similar to the impossibility of proving the existence of the external world. ${ }^{11}$ While we cannot prove the external world's existence, it is rational, and even necessary, for us to trust our experience. "That is to say, we are so constituted that we cannot help believing and living in terms of the objective reality of the perceived world."12 The same is true for religious experience. Those who vividly experience their lives in relation to a transcendent reality are behaving rationally when they trust this experience and believe that this reality exists. In fact, such persons would be irrational not to trust this experience.

Initially, John Hick has mahatmas, or people at the origin of the great religions, in mind for people who experience a transcendent reality in this clear and vivid manner. He uses the specific example of Jesus who "was vividly aware of 'living in the unseen presence of God' as abba, father. God, as personal loving will, was as real to him as his neighbours or as the hills and rivers and lake of Galilee. The heavenly father was not a mere concept or a hypothetical entity, but an experienced living reality. .."13

\footnotetext{
${ }^{10}$ Hick, An Interpretation of Religion 211.

${ }^{11}$ Hick, An Interpretation of Religion 213.

${ }^{12}$ Hick, An Interpretation of Religion 213.

${ }^{13}$ Hick, An Interpretation of Religion 216.
} 
After arguing for the rationality of religious belief of mahatmas based upon their vivid religious experience, Hick then proceeds to answer the obvious question concerning the religious beliefs of the ordinary person. While their beliefs can never be as grounded as the beliefs of the great mahatmas, if "one experiences one's own life religiously, even only occasionally and to some slight extent, this makes it both possible and reasonable to be so impressed by the reports of the mahatmas that one's own experience is supported by their much more massive awareness of the transcendent." ${ }^{14}$ So, for Hick, the rationality of religious belief is always grounded in experience, whether it is the vivid experience of the great religious leaders, or the less vivid experience of the common person which then relates to the accounts of the mahatmas.

In the dialogue with William Alston, Hick argues that the central premise that religious belief is justified only by religious experience undermines the position that there is at most one true religion. The central issue in this dialogue concerns the epistemology of religious beliefs. Hick begins to describe this problem by pointing out that most contemporary philosophers of religion are in agreement that "the most viable defence of religious belief has to be a defence of the rationality of basing beliefs ... on religious experience." ${ }^{15}$ This defense of religious belief, however, poses problems for the Christian philosopher because the epistemological stance applies not just to Christianity, but to the other world religions as well. Thus, "the same epistemological principle establishes the rationality of Jews, Muslims, Hindus, Buddhist etc. in holding beliefs that are at

\footnotetext{
${ }^{14}$ Hick, An Interpretation of Religion 223.

${ }^{15}$ Hick, Dialogues in the Philosophy of Religion 25.
} 
least partly, and sometimes quite radically, incompatible with the Christian beliefsystem." 16

Hick cites Alston's proposed solution to the problem of religious diversity as presented in his work Perceiving God: "Alston's solution to the problem is (in briefest summary) that since we have at present no neutral way of establishing which of the world religions is right, and since our own religion is both theoretically and practically satisfactory to us, it is much more reasonable for us to stay with it than to switch to another."17 Hick's critique hinges upon what he takes as an assumption in Alston's position, namely that there can at most be one true religion. Hick points out that the proposition 1) 'religious belief is rational because it is based upon religious experience' and the proposition 2) 'there is at most one true religion' are contradictory. "For if only one of the many belief systems based upon religious experience can be true, it follows that religious experience generally produces false beliefs, and that it is thus a generally unreliable basis for belief-formation." 18

Hick maintains that this contradiction is so strong that Alston's position is unable, without 'radical adjustment' to "meet the challenge of religious diversity to his experience based apologetic."19 Hick then alludes to his own position by claiming that Alston's first proposition seems correct, but that it would be a "much

\footnotetext{
${ }^{16}$ Hick, Dialogues in the Philosophy of Religion 25.

${ }^{17}$ Hick, Dialogues in the Philosophy of Religion 25.

${ }^{18}$ Hick, Dialogues in the Philosophy of Religion 26.

${ }^{19}$ Hick, Dialogues in the Philosophy of Religion 27.
} 
stronger contribution if the doxastic practices of the other world religions could be seen as further instances of it rather than as contradicting it." 20

Alston's original response is very brief, but he answers Hick's critique in two ways. According to Alston, Hick's position that the assumption of one true religion necessitates that religious experience generally produces false belief, and is therefore unreliable, is misleading. "First, it assumes that most of the beliefs in each system contradict most of the beliefs in the others. But that is by no means clear, and in the absence of any definite way of counting, it could not be clear." ${ }^{21}$ Second, Alston claims that Hick misrepresents his view by inflating the role that religious experience has in justifying religious beliefs. Alston maintains that while religious experience is important for grounding religious beliefs, it also interacts with other grounds such as natural theology and revelation. ${ }^{22}$ "Thus, even if the major religious belief systems are mostly in contradiction, there is still the question of the extent to which this is to be laid at the door of religious experience."23

Alston additionally points out that even if the beliefs grounded in religious experience were false, that would not contradict the epistemological claims he makes for religious experience. ${ }^{24}$ Here, Alston claims that religious beliefs based upon religious experience are only prima facie justified; that is, they can be

\footnotetext{
${ }^{20}$ Hick, Dialogues in the Philosophy of Religion 27.

${ }^{21}$ William Alston, "Section 2(i)(b)," Dialogues in the Philosophy of Religion, ed. John Hick (New York: Palgrave, 2001) 37.

${ }^{22}$ Alston, 37.

${ }^{23}$ Alston, 37.

${ }^{24}$ Alston, 38 .
} 
overridden by other factors. He does not explain this position thoroughly until his second response.

In the next section, Hick responds to each of Alston's points in direct fashion. Concerning Alston's first point that it is not clear that most of the beliefs in each system contradict most of the beliefs in the other, Hick answers that while this is true, his argument only requires that the central beliefs contradict one another, which can hardly be denied to be the case. "So I do not think that Alston's first response deflects the criticism that it is intended to deflect. He has pointed out, correctly, that his position does not apply to all religious beliefs, but it still does apply to the most central ones."25 Hick also grants that Alston's position in his book Perceiving God does include that other factors, such as natural theology and revelation, are at play in grounding religious belief in rationality, creating a 'mutual evidential network'. But this does not alleviate the problem of religious diversity. Even if one were to grant that these other factors are involved, each of the great world religions would still be "epistemically equally well based, supported by religious experience, supposed revelation, revered scripture, inspiring role models and a more general uplifting effect in people's lives; and natural theologies that would exclude the non-theistic faiths by providing a personal Creator, do not succeed in doing so."26

The last section of the dialogue is a fuller response from Alston to the criticism of Hick. He notes that there are two assumptions that he must hold in order for Hick's criticism to be valid. The first is that there is a good amount of

\footnotetext{
${ }^{25}$ Hick, Dialogues in the Philosophy of Religion 40.

${ }^{26}$ Hick, Dialogues in the Philosophy of Religion 41.
} 
incompatibility between the beliefs of the world religions. The second is that, of these incompatible beliefs, a good amount of them are grounded in religious experience, or as Alston states "mystical perception".

What Hick needs for his criticism is merely that I accept these assumptions. And this is how his premise that I hold that 'Christianity is the only fully true religion' comes into the argument. For, as noted above, he derives from this that I am thereby committed to holding that 'religious experience within other religions produces beliefs that are false in so far as they are incompatible with Christian belief'. But it is very important to note that this consequence need not be so derived. ${ }^{27}$

So, the rest of this response is dedicated to the task of showing that it is not religious experience in and of itself that produces false beliefs.

Alston states that he is "prepared to acknowledge that ... there is a considerable degree of incompatibility between central beliefs of different religions" ${ }^{\prime 2}$, but that is detrimental to his argument only if the incompatibilities result from mystical perception-based beliefs. However, mystical perception mainly produces 'manifestation' beliefs, or 'beliefs as to what perceivable features God has and as to what He is doing vis-à-vis the subject.."29 These manifestation beliefs, however, are not the source of incompatibilities between the major religions. Incompatible beliefs between the world religions have to do with "the central beliefs about the Ultimate, its (his, her) nature, general activities, purposes, etc., rather than how it is related to this or that individual, or what its perceivable features are. ${ }^{30}$

\footnotetext{
${ }^{27}$ Alston, 43.

${ }^{28}$ Alston, 44 .

${ }^{29}$ Alston, 44.

${ }^{30}$ Alston, 45 .
} 
Alston attempts to further his defense by introducing the notion of an 'overridder system' which was only touched upon in his first response. "Religious experience can provide significant justification for religious beliefs only if it is set in the context of an 'overridder system' for assessing the credentials of any particular belief based on that experience. ${ }^{31}$ An overridder system basically just consists of the central beliefs of a particular religion, so that each religion can be said to be an overridder system from which mystical experience-based beliefs can be judged. But if the system itself is faulty, it will incorrectly assess the beliefs. "Thus, if a considerable proportion of the beliefs of a religion are false, mystical perception within that religion cannot be relied on to produce mostly true beliefs, since the overridder system employed, containing many false beliefs, cannot be depended on to separate the wheat from the chaff." ${ }^{\prime 32}$

John Hick does not respond to this response, and the dialogue ends here. But it is easy to anticipate how Hick might respond. First of all, by introducing the notion of the overridder system, Alston has shifted the power of justification of religious beliefs from religious experience to the overridder system, or the religion itself. Hick notes in his original critique of Alston that Alston maintains that "the most viable defence of religious belief has to be a defence of the rationality of basing beliefs (with many qualifying provisos which Alston has carefully set forth) on religious experience. ${ }^{33}$ (emphasis added) But these many qualifying provisos diminish the importance of religious experience in rationalizing religious beliefs. Alston's position seems to be that religious experience rationalizes religious

\footnotetext{
${ }^{31}$ Alston, 45.

${ }^{32}$ Alston, 45.

${ }^{33}$ Hick, Dialogues in the Philosophy of Religion 25.
} 
beliefs, but only if they are in line with a satisfactory system, or, in other words, a true religion. But Alston himself admits that he gives no criteria for which to judge the various overridder systems. Alston recognizes that his case for religious experience must form a part of a cumulative case for Christianity: "the final stage of my programme was missing. I shied away from any attempt critically to evaluate the Christian belief system in general.. ${ }^{34}$ While Alston believes that the defense of Christianity on neutral grounds "can be given some substance ${ }^{\prime 35}$, he admits that this has not yet been done. Hick is correct in maintaining that until this is done, the problem of religious pluralism seems to remain for the exclusivist.

This dialogue serves as a good introduction into the problem of religious pluralism for a number of reasons. First, it begins to highlight the three main positions: exclusivism, inclusivism, and pluralism. Exclusivism maintains that there is only one true religion and that adherence to that one true religion is the only way to achieve the only religious end. The inclusivist also maintains that there is only one fully true religion, but also holds the belief that people of other religions can achieve salvation. For instance, the Christian inclusivist claims that Christianity is the only true religion, but the grace of God and the power of Christ are sufficient to include adherents of other religions. Finally, the pluralist believes that there is no one true religion. Rather, all of the major religions are on equal footing in their relation to the transcendent.

\footnotetext{
${ }^{34}$ Alston, 48 .

${ }^{35}$ Alston, 38.
} 
This dialogue also serves as a good introduction because through the method of critique, Hick is able to argue why there is a need for his positive work, his pluralistic hypothesis. Ultimately, I contend that Hick and Alston are at an impasse which is caused by their fundamentally different views on the importance of religious experience. We have seen how Alston's qualifying provisos diminished the importance of religious experience in his philosophy. But for Hick, religious experience proves central for establishing the rationality of religious belief, and is, consequently, fundamental to his hypothesis.

As was shown in this dialogue, anyone who holds the position that religious experience is what grounds religious belief in rationality invites the problem of religious pluralism. "For if the different kinds of religious experience justify people in holding incompatible sets of beliefs developed within the different traditions, has not our justification for religious belief thereby undermined itself?"36 If we accept Hick's argument of the rationality of religious beliefs, we seem to be faced with this problem. In an attempt to solve this problem, Hick posits his hypothesis.

\footnotetext{
${ }^{36}$ Hick, An Interpretation of Religion 228.
} 


\section{Chapter 2}

\section{Explanation of Hick's Pluralistic Hypothesis}

In the briefest way, Hick's pluralistic hypothesis can be stated as follows: "The great post-axial faiths constitute different ways of experiencing, conceiving and living in relation to an ultimate divine Reality which transcends all our varied versions of it." ${ }^{\prime 37}$ To flesh this out, Hick begins by making a distinction between 'the Real' [the transcendent divine reality] an sich and 'the Real' as humanly experienced by different people. 'The Real' an sich is 'the Real' as it is independent of people's experiences of it. It is 'the Real' in itself, as it is unable to be perceived. Distinguished from 'the Real' an sich is 'the Real' as it is humanly experienced. This is not 'the Real' as it is in itself, but 'the Real' as it appears to human consciousness. Moreover, this appearance to human consciousness occurs in myriad ways. 'The Real' appears to different people in different cultural and historical contexts in different ways. This then accounts for the plurality of religious traditions.

In order to fully understand the second half of Hick's distinction, one must first understand his views on experience, or as he calls it, 'experience-as'. Hick argues that we never just passively experience any object, but always experience objects as something. That is, we always bring a certain background

\footnotetext{
${ }^{37}$ Hick, An Interpretation of Religion 235-6.
} 
and certain theories to experience. He borrows this idea from Wittgenstein, but expands it to cover more area than Wittgenstein intended. Wittgenstein wrote about ambiguous picture puzzles, in which the picture could be seen in one of two ways. For instance, the picture may be seen as a young French woman looking to the right or, conversely, as an old witch looking to the left. Given the ambiguity, Wittgenstein pointed out that we have to see the picture as one or the other, so we just don't see the picture.

Whereas Wittgenstein limited this 'seeing-as' to the puzzle picture, Hick contends that all seeing is seeing-as and even all experience is experience-as. To show this, Hick uses the example of seeing a fork on the table. The fork is so familiar an object that it seems strange to say that we are seeing the object on the table as a fork. "However we have more usual names for ordinary seeing-as in real life: we call it 'recognising' or 'identifying." ${ }^{38}$ Even in the everyday occurrence of seeing a fork, we are seeing it as a utensil for eating. However, the only reason why we see the fork as a utensil for eating is because we bring to this experience a certain background. We come from a culture, time, and place where objects of this type are used for eating, so we see them as such.

However, someone from a very different culture might not see the fork as a tool for food consumption. Depending on their background, they may see it as a piece of decorative art, a hair comb, or an object to be feared and worshipped. "But they would not have the concept of a fork with which to identify it as a fork.

\footnotetext{
${ }^{38}$ Hick, An Interpretation of Religion 141.
} 
Indeed to say that they do not have this concept and that they cannot perform the act of recognition are two ways of saying the same thing."39

For Hick, experiencing-as, or more specifically seeing-as, is to apply a linguistic concept to an object being perceived. This process of concept applying is something humans do automatically when they focus upon objects. I cannot look outside my window and see a chimney without applying the concept of chimney to it; I automatically see it as having a certain use and function. This concept is created by the linguistic environment of which I am a part. "These conceptual creations are the inner skeletons structuring the various forms of life, or ways of being human, that constitute the different cultures of the earth."

The notion of experience-as is crucial to understanding the second half of the distinction of 'the Real', that is 'the Real' as humanly experienced. For this notion of experience-as not only applies to forks and picture puzzles, but also to human experiences of the Real. When someone experiences the Real, they automatically apply their linguistic concepts to it. The way they experience the Real is shaped by their language, culture and history; it is shaped by their 'way of being human'.

Given that there are multiple ways of being human and that the Real is always experienced through this lens, the fact of religious pluralism begins to be explained. On this hypothesis, while the Real an sich is what all of the great religions are related to, multiplicity occurs not because all religion is illusion and imagination, nor because one religion is right while others are deluded or

\footnotetext{
${ }^{39}$ Hick, An Interpretation of Religion 141.

${ }^{40}$ Hick, An Interpretation of Religion 142.
} 
incomplete, but because all experience of the Real is 'experience-as'. Just as seeing the picture puzzle as a young French woman is just as valid as seeing it as the old witch, so each of the great religions are equally valid experiences of the Real.

There is also a limiting nature to the notion of experience-as. By seeing the fork as a utensil for food consumption, I have limited my experience of it to that concept. I am therefore unable, at the same time, to experience it as a piece of decorative art or an object to be feared and worshipped. Likewise, the experience of the Real as a personal deity, as in Jewish experience, is limited to that concept. If I experience the Real as a personal deity, I am unable, at the same time, to experience it as a non-personal absolute common in Buddhist experience. So while all of the major religions are equally valid ways of experiencing the Real, they are all also limited and incomplete.

In developing his hypothesis, Hick draws heavily upon the philosophy of Kant. He does not draw upon Kant's epistemology of religion, but upon his understanding of sense perception, which is then expanded by Hick to formulate his own epistemology of religion. In examining sense perception, Kant noticed that the same object could be perceived differently by different people. This led him to distinguish between the world an sich, as it is itself, unperceived and the world as perceived by finite minds. He used the term 'noumenon' to refer to the former and the term 'phenomenon' for the latter.

Hick expands Kant's insight of sense perception to cover religious experience. Kant showed that we sense perceive objects, which gives rise to us 
postulating the objects' noumenal existence. Hick claims that we religiously experience the Real which gives rise to the postulation of the Real as it is itself. It is important, however, to note that the 'noumenon' for Kant is not knowable by any human faculty and the phenomenon has empirical reality. "Analogously, [Hick wants] to say that the noumenal Real is experienced and thought by different human mentalities." ${ }^{41}$ These different experiences are "not illusory but are empirically, that is experientially, real as authentic manifestations of the Real." ${ }^{42}$ So, it seems that it might be dangerous to view this as a Reality/appearance distinction because the term appearance suggests a lack of reality. For Hick, a phenomenon of the Real has empirical reality, just as the phenomenon of the chimney outside my window has empirical reality.

Before moving on to see how this hypothesis plays out, there are a couple of obvious questions, upon which certain critiques of Hick are based, which Hick addresses. First of all, why does Hick maintain that each of the traditions is experiencing the same transcendent? Could it not be the case that for each religion the noumenon behind the phenomenon is different and distinct? To answer this, Hick appeals to Ockham's razor. "The 'truthfulness' of each tradition is shown by its soteriological effectiveness. But what the traditions severally regard as ultimates are different and therefore cannot all be truly ultimate. They can however be different manifestations of the truly Ultimate within different streams of human thought-and-experiences - hence the postulation of the Real

\footnotetext{
${ }^{41}$ Hick, An Interpretation of Religion 242.

${ }^{42}$ Hick, An Interpretation of Religion 242.
} 
an sich as the simplest way of accounting for the data." ${ }^{43}$ Secondly, why postulate the Real an sich at all? "The answer is that the divine noumenon is a necessary postulate of the pluralistic religious life of humanity."44 He argues that if the Real an sich is not postulated then one must take either the position that religious experience is illusory or the position that the only religious experience that is not illusory is one that comes from one particular tradition or stream of thought. "But for those to whom neither of these options seems realistic the pluralistic affirmation becomes inevitable, and with it the postulation of the Real an sich, which is variously experienced and thought as the range of divine phenomena described by the history of religion." 45

To further develop his hypothesis, Hick turns toward the task of showing how this hypothesis has played itself out in the history of religion. He notices two main ways in which the Real has been experienced, as personae and as impersonae. Concerning the personae, Hick shows that all of the major religious traditions have thought of the transcendent reality in personal terms. This, of course, is obvious in the Semitic traditions, but Hick shows that it is not limited to them. For example, in Mahayana Buddhism, "Buddha has been elevated, not merely by popular imagination but by religious reflection, from the greatest of human teachers to a being of universal power and significance" and "is referred to in the Lotus Sutra as Devatideva, supreme god of the gods." ${ }^{46}$ Even the adherents of the more philosophical traditions, such as Taoism and

\footnotetext{
${ }^{43}$ Hick, An Interpretation of Religion 248-9.

${ }^{44}$ Hick, An Interpretation of Religion 249.

${ }^{45} \mathrm{Hick}$, An Interpretation of Religion 249.

${ }^{46}$ Hick, An Interpretation of Religion 256.
} 
Confucianism, "seem to have needed to think of the transcendent as a personal reality or realities, able to be approached by means of ritual, prayer and sacrifice." ${ }^{47}$

After Hick demonstrates the pervasiveness of personal deities in the major world religions, which according to his hypothesis would be the pervasiveness of the Real being experienced in a variety of personal ways, he then turns to the task of examining these experiences phenomenologically.

Given that there is this almost universal propensity of the human mind to think-and-experience the presence of the Real in personal terms, what is the status and nature, from the point of view of our pluralistic hypothesis, of the numerous gods, goddesses and mono-deities? As an approach to this question we shall do well first to take note of their phenomenological character. ${ }^{48}$

Hick distinguishes between experiences of the Real and philosophical or theological reflections of the Real; or as Pascal labeled the distinction, "between the God 'of the philosophers and scholars' and the 'God of Abraham, God of Isaac, God of Jacob." ${ }^{49}$ He notes that the experienced personae of the Real are never experienced as infinite. Infinity is a concept that exceeds experience and, according to Hick, has been attributed to God through the second order business of philosophy and theology, not through religious experience. ${ }^{50}$ In Jewish experience certain qualities of God, such as goodness or justness, may be experienced as unending in the sense that they extend beyond the experiential horizons of the one who experiences God, but this is not an experience of infinity. "But the point [Hick wants] to stress is that the experienced divine personae are

\footnotetext{
${ }^{47}$ Hick, An Interpretation of Religion 257.

${ }^{48}$ Hick, An Interpretation of Religion 257.

${ }^{49}$ Hick, An Interpretation of Religion 258.

${ }^{50}$ Hick, An Interpretation of Religion 259.
} 
not phenomenologically infinite, although - according to our hypothesis - they

are manifestations within finite human experience of the Real which, being truly ultimate, has no limits."

Hick develops his concept of divine personae by way of analogy with the psychological concept of personae. He writes that a person is made up of character and personality. "The character is the underlying and only slowly changing ground-plan which the personality expresses, whilst the personality is the conscious surface [or public 'face'] which lives in interaction with other selves." 52 The character of a person is analogous to the Real an sich and the personality of a person is analogous to the various divine personae taken as a whole. A persona of a person is "a role that one builds within a certain group" 53 and a particular persona of a person is, of course, analogous to a particular persona of the Real, otherwise known as a deity.

According to our hypothesis the Real is always present to human life, with our capacity for religious awareness; and in its theistic forms that presence consists in various divine personae who are known in different streams of religious history. Each of these has an experienced social reality and power within the life of the worshipping community in relation to which it has been formed, and it constitutes the Real as perceived and responded to by that community. ${ }^{54}$

Hick admits that this analogy is not perfect, for it is not a greater self that is behind the various divine personae, but simply the ultimate ground beyond human conception. But it does serve as a nice model that clarifies and develops the pluralistic hypothesis.

\footnotetext{
${ }^{51}$ Hick, An Interpretation of Religion 263-4.

${ }^{52} \mathrm{Hick}$, An Interpretation of Religion 264.

${ }^{53}$ Hick, An Interpretation of Religion 265.

${ }^{54}$ Hick, An Interpretation of Religion 266.
} 
The question of the ontological status of these various divine personae remains for Hick to answer. In an attempt to do this, Hick suggests two possible models, the Christian doctrine of the trinity and the Buddhist trikaya doctrine, and ultimately contends that the latter is the best model for the present purposes. According to this doctrine, there are three modes of the infinite Buddha-nature. Hick concerns himself primarily with the second mode, the Sambhogakaya, which is "the 'Body of Bliss', consisting in a plurality of transcendent Buddhas." 55 The ontological status of this 'Body of Bliss' has been traditionally understood in two ways. The first way sees the body as mental creations that become so vivid that they acquire a subjective reality.

To clarify this, Hick compares it to the parapsychological concept of 'veridical hallucinations'. This occurs when one person is made telepathically aware of another person's death via a vision of that person. "The experience is technically hallucinatory in that there is no physical body in the region of space which the apparition seems to occupy... But it is a veridical hallucination in that through it authentic information about $B$ is being transmitted to $A ., 56$ If understood in this way, the experienced divine persona (while not usually experienced visually) has no objective reality, but it does "constitute a transformation of authentic information of which the Real is the ultimate source. ${ }^{.57}$ Given that the source of the persona is the Real, it would still be appropriate to worship this persona. For whether or not the worshipper realized

\footnotetext{
${ }^{55}$ Hick, An Interpretation of Religion 272.

${ }^{56}$ Hick, An Interpretation of Religion 273.

${ }^{57}$ Hick, An Interpretation of Religion 273.
} 
its subjectiveness, the persona would still be a means of mediating the relationship between herself and the Real. ${ }^{58}$

In Buddhist tradition, the Sambhogakaya has also been understood to have objective reality so that the transcendent Buddhas are objectively existing, supernatural beings. ${ }^{59}$ "Applying this conception to Jahweh, Vishnu, Allah, Shiva, the heavenly Father and so on it would follow that they are real personal beings, independent centres of consciousness, will, thought and emotion." ${ }^{\circ 0}$ If this is correct it must be remembered that these personal beings are not infinite, "for each exists alongside and is limited by the others with their particular natures and capacities." ${ }^{61}$ Ultimately, Hick does not answer the question of the ontological status of the personal phenomenon of the Real. He states that "the pluralistic hypothesis being propounded here could accommodate either of these models and does not require a decision between them. It therefore seems wise not to insist upon settling a difficult issue which, in logic, the hypothesis itself leaves open." 62

After developing his hypothesis by explaining the concept of the personae of the Real, Hick then extends his hypothesis to include what he calls the Impersonae of the Real. From the point of view of the pluralistic hypothesis, Impersonae are manifestations of the Real as non-personal, religious Absolutes. Hick deals specifically with the Hindu absolute of Brahman and the Buddhist absolute of Nirvana/Sunyata. Concerning Brahman, he distinguishes between

\footnotetext{
${ }^{58}$ Hick, An Interpretation of Religion 273.

${ }^{59}$ Hick, An Interpretation of Religion 274.

${ }^{61}$ Hick, An Interpretation of Religion 274.

${ }^{61}$ Hick, An Interpretation of Religion 275.

${ }^{62}$ Hick, An Interpretation of Religion 275.
} 
nirguna Brahman and saguna Brahman. "The highest reality, containing no element of illusion, is nirguna Brahman, Brahman without attributes, beyond the scope of human thought and imagination. Less high, because involving some element of illusion, is saguna Brahman, Brahman with attributes, known as Ishwara, the personal creator and lord of the universe." ${ }^{63}$ Hick then further distinguishes satchitananda, which Brahman is also often called. This, however, is not a deity like saguna Brahman, but a mystical state of being, pure consciousness and bliss. Given that nirguna Brahman is completely ineffable, beyond all human concepts, Hick cites it as being equal to the Real an sich while saguna and satchitananda Brahman are different phenomenal manifestations of the Real. "In offering this proposal from the standpoint of the pluralistic hypothesis I am treating the trans-personal reality of satchitananda. . . and the personal Reality of Ishwara. . . as alternative manifestations of the Real to our human consciousness. Thus in this formulation the Real an sich is equated with nirguna Brahman, whilst both satchitananda and Ishwara are identified forms of saguna Brahman." 64

When considering Buddhism and its relation to the pluralistic hypothesis, Hick concentrates on two concepts: Nirvana and Sunyata. These two concepts are central to two different branches of Buddhism, Theravada and Mahayana Buddhism respectively. For Theravada Buddhism, Nirvana is the mystical experience achieved when liberation from bondage to the ego occurs. "From the point of view of our pluralistic hypothesis Nirvana is the Real experienced in an

\footnotetext{
${ }^{63}$ Hick, An Interpretation of Religion 280.

${ }^{64}$ Hick, An Interpretation of Religion 282-3.
} 
ineffable ego-lessness, unlimited and eternal, which can be entered by the moral and spiritual path taught by Buddha." ${ }^{\text {65 }}$ According to the hypothesis, the Mahayana experience of Sunyata is also an experience of the Real, not as it is in itself, but through a particular cultural lens.

The Mahayana tradition claims that Sunyata is an unmediated experience of the Absolute, but Hick concludes by arguing that this is in all probability not the case.

However does not the fact that there are a number of different traditions of unitive mysticism, offering their characteristically different reports of the nature of the Real, make it seem more likely that the otherwise universal structure of human consciousness holds here also, and that that which is being directly experienced is not the Real an sich but the Real manifested respectively as Sunyata, as Brahman, as God? ${ }^{66}$

For Hick, the data of multiple but different and seemingly incompatible claims to unitive experience with the Ultimate Reality suggests that even in highly mystical experiences, the mind still "operates with culturally specific concepts and that what is experienced is accordingly a manifestation of the Real rather than the postulated Real an sich."67

Thus far, we have seen through the Hick/Alston debate why Hick maintains that there is a problem of religious diversity that needs to be addressed. I have explained Hick's solution to this problem, which is his pluralistic hypothesis. I have further shown the way this hypothesis has played itself out in the history of religion. I will now turn my attention to various critiques of Hick's hypothesis before giving my own critique and response.

\footnotetext{
${ }^{65}$ Hick, An Interpretation of Religion 287.

${ }^{66}$ Hick, An Interpretation of Religion 294.

${ }^{67}$ Hick, An Interpretation of Religion 295.
} 


\section{Chapter 3}

\section{Critiques}

One type of critique that will be presented concerns Hick's overall empiricist position, specifically in his argument for the meaningfulness of religious language, and how this position relates to his hypothesis. Before presenting these critiques, I will first cover what this basic empiricist position entails for Hick and how he uses it to argue for religious meaningfulness.

Beginning in the 1920's, the philosophical movement of logical positivism, which was associated with empiricism, argued for the 'verifiability criterion of meaning'. This is the notion that in order for a proposition to be cognitively meaningful, it must be able to be verified through observation. Given that God's existence is unable to be verified through observation, religious propositions were excluded and deemed cognitively meaningless.

Hick claims that while the logical positivist movement is a thing of the past, some of their central insights are not a thing of the past and need to be addressed presently. In his paper "Eschatological Verification Reconsidered" (1977), Hick writes that "the central core of the positivist contention seems undeniable. For it is simply the basic empiricist position that to exist, or to be the case, is to make a difference. That is to say, to assert that $x$ exists is to assert an 
in-principle-observable difference between the actual universe and a possible universe which differs from it only in that the latter does not include $x .{ }^{\text {"68 }}$ Hick notes that the assumption of the logical positivist that this in-principle-observable difference must be of the kind detected in sense data was simply 'an a priori dogma'. ${ }^{69}$ However, despite this positivist dogma, "it is a perfectly good question to ask one who asserts that God exists, or that a divine purpose is being fulfilled in human life, what in-principle-experienceable difference it makes whether God exists or whether a divine purpose is being fulfilled in human life."70

What, then, counts as an experienceable difference? To answer this, Hick distinguishes between simple and complex verifiability. The truth values of certain statements are able to be verified by simple observation. These include statements like "There is a table in the next room". One can simply look into the next room, see the table, and thus verify the truth of the statement. Other propositions (ex. "John Smith is an honest man") require cumulative observations. Theistic statements, along with most scientific theories, belong to this second variety. "This distinction between simple and complex verifiability enables us to avoid a wrong approach to the question of the verification of theistic statements. We should not ask, what single observation would verify them, but what development of our experience would progressively confirm them to the point at which there is no longer any room for rational doubt?."71

\footnotetext{
${ }^{68}$ John Hick, "Eschatological Verification Reconsidered," Religious Studies 13 (1977): 192.

${ }^{69}$ Hick, "Eschatological Verification Reconsidered" 192.

${ }^{70}$ Hick, "Eschatological Verification Reconsidered" 192.

${ }^{71}$ Hick, "Eschatological Verification Reconsidered" 194.
} 
Thus, according to Hick, the verifiability of the claims of the particular theistic traditions consists not in a direct observation of God, but "in experiencing features of the universe, as it changes through time, which trace the difference that the existence of God makes. These constitute the fulfillment of the divine purpose for creation."72 Accordingly, if the claims of Islam or of Christianity are true, we will be able to verify this in the eschaton, when our awareness of God will "no longer be in tension with the circumstances of $\sin$ and suffering, ugliness and deprivation, which at present leave room for rational doubt."73

In his article entitled "The Pluralistic Hypothesis, Realism, and PostEschatology", S. Mark Heim gives an internal critique of John Hick's work An Interpretation of Religion. He criticizes Hick on a number of fronts. He argues that two of Hick's arguments, the argument for religious meaningfulness and the justification of religious belief, do not support his pluralistic hypothesis.

Moreover, he argues that these two arguments, taken together, "raise serious questions about whether Hick's hypothesis actually succeeds in asserting a meaningful truth claim." 74

Heim summarizes Hick's argument for religious meaningfulness and mentions Hick's contention that "religious convictions and faith are meaningful and have cognitive content precisely because there are conditions under which evidence sufficient for determination of their truth or falsehood will obtain." ${ }^{75}$ Hick argues that religious content is meaningful because there is a situation in which

\footnotetext{
${ }^{72}$ Hick, An Interpretation of Religion 178.

${ }^{73}$ Hick, "Eschatological Verification Reconsidered" 196.

${ }^{74}$ Mark S. Heim, "The Pluralistic Hypothesis, Realism, and Post-Eschatology," Religious Studies 28 (1992): 207.

${ }^{75}$ Heim, 211.
} 
the claims of a particular religion can be verified. While they cannot be verified currently, eschatological verification makes religious claims meaningful.

Heim turns this argument around on Hick. He claims that if possible verification is what makes claims meaningful, then there are serious doubts as to whether claims of the pluralistic hypothesis are meaningful.

However, the sole religiously significant content which Hick allots to the religious traditions - that there is a noumenal ultimate Real impinging upon us, in relation with which humans are transformed by realitycenteredness toward a limitlessly better possibility - must itself be subject to eschatological verification to be meaningful and true. If not, then Hicks tenacious argument for a realistic verses a non-realistic view of religion has the ironic effect of vindicating the truth value of the particular religious traditions but denying it to his own pluralistic hypothesis. ${ }^{76}$

Heim then asks the obvious question. What possible situation would confirm that there is a noumenal Real behind all of the great religions in relation to which the religious are being transformed to a 'limitlessly better possibility'.

Heim maintains that the pluralistic hypothesis, as stated by Hick, is in principle unverifiable even under eschatological circumstances for two reasons. "First, it is hard to see how any experience of fulfillment could constitute verification of a 'limitlessly better possibility'."77 Even if a post-mortem or eschatological experience surpassed all of our hopes, how could we ever know it to be limitlessly better?

Secondly, and more importantly, "whatever experience of beatitude might be encountered in such a condition, the assertion that it is a single noumenal 'Real' which is the source of this experience is just what could not be verified." ${ }^{78}$

\footnotetext{
${ }^{76}$ Heim, 211.

${ }^{77}$ Heim, 212.

${ }^{78}$ Heim, 212.
} 
Heim argues this point by showing that Hick's notion of experience ('experience as') would still apply eschatologically and prevent one from experiencing the Real an sich, or, in other words, experience the Real as it is unable to be experienced. Hiem points out that Hick might object that any eschatological fulfillment or combination of eschatological fulfillments is compatible with his hypothesis. But Heim argues that, while this is true, it is just a further suggestion that the hypothesis is empty. ${ }^{79}$ Even if the eschaton were experienced by a Christian as conforming exactly or very closely to what the Christian belief system says to expect, this also would be compatible with Hick's hypothesis. But it by no means verifies it, for this experience would also be compatible with the Christian exclusivist position. "The fact of the matter is that any such fulfillment would be powerful evidence for the cognitive validity of that specific religious tradition or combination of traditions and their accounts of themselves, in preference to Hick's account. There would be nothing at all distinctively confirmatory of Hick's hypothesis in such a situation, since his hypothesis asserts something over and above the specific traditions." 80

Heim's main critique thus far seems to be as follows: Hick holds the position that in order for a proposition to be meaningful it must have the possibility of being verified through experience. It is evident that Hick holds this position; otherwise he would not feel the need to appeal to eschatological verification in his argument for religious meaningfulness. However, Hick's idea of the noumenal "Real" is the Real as it is unable to be experienced. If the

\footnotetext{
${ }^{79}$ Heim, 213.

${ }^{80)}$ Heim, 213.
} 
noumenal "Real" is unable to be experienced, it seems that this condition would also apply in the eschaton. Therefore, Hick's propositions concerning the noumenal "Real", even those propositions simply asserting its existence, are meaningless. Therefore, while arguing for the meaningfulness of the language of particular religions, he has denied meaningfulness to his pluralistic hypothesis.

After Heim uses Hick's argument for religious meaningfulness against his pluralistic hypothesis, he does the same with Hick's argument for the justification of religious belief. Heim states that Hick is unwarranted to move from the fact that beliefs from different traditions are equally justified to the hypothesis that there is one noumenal object behind all their views. "This hardly follows. The thought just outlined leans heavily on the implicit suggestion that equally justified beliefs ought in some sense to be equally true (or false). ${ }^{.81}$

At this point of the critique, however, Heim is guilty of misrepresenting Hick's argument. Hick is not claiming that there is a logical connection between the fact that there are different, seeming incompatible, justified religious beliefs and his pluralistic hypothesis. His hypothesis is just that, a hypothesis. It is a position tentatively assumed and its successfulness will be determined by how well it makes sense of certain facts and experiences. It is not meant to be something deduced from facts.

However, Heim continues to the strongest part of the critique when he argues that Hick's hypothesis is completely ineffective precisely because it is compatible with every possible state of affairs and that it is impossible to either verify it or falsify it. To argue this, Heim again draws on Hick's argument for the

${ }^{81}$ Heim, 215. 
justification of religious beliefs. Heim notices that in Hick's argument for the rationality of religious beliefs that "it is only the current justification of belief which is unaffected by future falsification. Under some future conditions, such religious beliefs might no longer be justified. Hick however does not present his hypothesis as a belief justified pending circumstances which will decide its validity, but apparently as a belief justified under any set of future circumstances." 82

This critique is, of course, parallel to his first argument. In the first he argues that Hick's hypothesis does not have the potential to be verified, even eschatologically. Even on Hick's own terms, this would make his hypothesis meaningless. In the second argument, Heim contends that Hick's hypothesis does not have the potential to be falsified. Given that it can be neither verified or falsified, Hick's hypothesis is unworkable and empty. "In short, the pluralistic hypothesis is a religious claim which falls afoul of the charge of emptiness against which Hick has fought so valiantly to defend religious claims in general." ${ }^{, 83}$

I contend that the critique given here by Heim poses a great challenge to the overall philosophy of John Hick. In chapter eleven of An Interpretation of Religion, Hick defends religious language against the charge of meaninglessness posed by the verificationist. If this chapter is viewed as being completely separate from the rest of the book, particularly the pluralistic hypothesis, then there is no real problem. The verificationists pose a challenge to religious

\footnotetext{
${ }^{82}$ Heim, 216.

${ }^{83}$ Heim, 218.
} 
language, and Hick defends religious language against the challenge through his notion of eschatological verification. But Hick fails to realize that this exact same challenge can be addressed to the language of his pluralistic hypothesis and he will not be able to respond in the same way.

Dr. Chester Gillis, in his article entitled "An Interpretation of $A n$ Interpretation of Religion", also focuses on Hick's appeal to verificationism as a point of critique. Unlike Heim, he does not notice how Hick's concession to verificationism could possibly be devastating to his hypothesis, but simply states that Hick should not appeal to this in his attempt to argue for religious meaningfulness.

Hick's continued concern with empiricism, particularly the logical-positivist variety, seems to be a concession to the validity of the whole enterprise of logical-positivism. Most scholars have dismissed this long ago as ill-fated and unworthy of further consideration. The criteria of the logical positivists are simply not well founded or acceptable. To continue to try to answer the question of the referent of religion on the grounds established by logical positivism is to concede validity to those grounds. ${ }^{84}$

Gillis' critique suggests a possible way for Hick to avoid the critique raised by Heim. If, as Gillis suggests, Hick could abandon concessions to logical positivism and verificationism and, instead, critique the entire enterprise, then perhaps, in so doing, he could support his claim to religious meaningfulness and at the same time avoid putting his entire hypothesis in jeopardy. But, judging from Hick's response to Gillis, in which he simply restates his argument given in his 1977 paper explained above, this seems to be a step he is unwilling to take.

\footnotetext{
${ }^{84}$ Charles Gillis, "An Interpretation of An Interpretation of Religion," Problems in the Philosophy of Religion, ed. Harold Hewitt, jr. (New York: St. Martin's, 1991) 37.
} 
Another strong critique comes from Paul Eddy who charges Hick with offering a hyper-subjectivist model and that, in the end, this necessarily must lead him to a Feuerbachian non-realism. He notes that Hick wants to retain a realist core, i.e. the noumenal Real, but be able to explain at the same time the diversity of understandings of this Real. The key to this is his insistence of the ineffability of the noumenal Real. "In this manner, he offers a religious realist as opposed to a naturalistic - interpretation of religion, while at the same time allowing the subjectivist component to create the space for radically divergent human understandings of the divine reality." 85

Eddy begins his critique by showing that Hick's attempt to ground the notion of divine ineffability in the various traditions is ultimately a failure because what Hick has in mind by the term 'ineffability' and what the thinkers of the various traditions, or at least Christianity, had in mind are quite different. Hick cites Augustine's declarative 'God transcends even the mind' and St. Thomas' 'The first cause surpasses human understanding and speech' as instances of claims to divine ineffability in the Christian tradition. ${ }^{86}$ Eddy claims that the religious thinkers' notion of divine infinity and ineffability suggest that 'the divine can never be exhaustively known. To admit that we can never know all of the divine is a far cry from claiming that we can never know anything of the divine."87

For Eddy, this ultra-subjectivist stance does serious damage to Hick's realist position. He cites Feuerbach's observation that:

\footnotetext{
${ }^{85}$ Paul R. Eddy, "Religious Pluralism and the Divine," Religious Studies 30 (1994): 468.

${ }^{86}$ Hick, An Interpretation of Religion 238.

${ }^{87}$ Eddy, 471.
} 
To deny all the qualities of a being is equivalent to denying the being himself. .. The denial of determinate, positive predicates concerning the divine nature is nothing else than a denial of religion, with, however, an appearance of religion in its favor, so that it is not recognized as a denial; it is simply a subtle disguised atheism ... Dread of limitation is dread of existence. ${ }^{88}$

Hick, however, does claim that while no substantial propositions can be applied to the noumenal Real, there are some purely formal and relational propositions that can be. "In this purely formal mode we can say of the postulated Real an sich that it is the noumenal ground of the encountered gods and experienced absolutes witnessed to by the religious traditions." 89 Eddy notices though that Hick is bringing in substance in his claims about the Real an sich. "To speak of purely formal properties is to speak solely in terms of relation, with absolutely no substantive content whatsoever. But clearly to say that $\mathrm{X}$ has the property of 'being a referent of a term' does have some amount of substantive content. If nothing else, it reveals that $X$ 'can be identified by some human language user'." ${ }^{90}$ For Eddy, all this shows the dilemma that Hick is in. "If, in reaction to Feuerbach's challenge, he allows for some substantive knowledge of the Real, the heart of his pluralistic programme is betrayed. Thus, Hick is destined to walk that neo-Kantian no-man's land that lies somewhere in an imaginary space between religious realism and a thoroughly subjectivized anti-realism."91

Hick directly responds to this critique in his article entitled "Religious Pluralism and the Divine: A Response to Paul Eddy". However, concerning

\footnotetext{
${ }^{88}$ Eddy, 472.

${ }^{89}$ Hick, An Interpretation of Religion 246.

${ }^{90}$ Eddy, 472.

${ }^{91}$ Eddy, 473.
} 
Eddy's application of Feuerbach's argument to the noumenal Real, Hick avoids the issue and simply states that:

It is of course true that, as Eddy says, it is possible to regard the entire phenomenon of religious experience as being 'accounted for by those religious concepts and sentiments found in religio-cultural systems and/or in the individuals themselves', and thus fall in line with Feuerbach. But this consideration is double edged. For the naturalistic option can be invoked against non-pluralist as easily as against pluralist religious views. It is not an argument that an exclusivist believer in the reality of the Divine can use against a pluralist believer in the reality of the Divine..$^{92}$

In a footnote, Hick informs the reader that it is obvious from other writings that Eddy is an exclusivist Christian. But Hick is failing to distinguish between the argument and the person arguing. The argument that Eddy offers in this particular critique still needs to be addressed by Hick, despite Eddy's views offered in other works.

Moreover, the specific challenge of Feuerbach to which Eddy is pointing would only apply to those, like Hick, that maintain that God (or 'the Real') is completely unknowable. For Feuerbach, to posit the existence of an unknowable God is to posit "a merely negative existence, an existence without existence, a self-contradictory existence, - a state of being which, as to its effects, is not distinguishable from non-being."93 This critique would not apply to those who hold that certain positive predicates can be applied to God. In his response, Hick seems to say that he does not need to respond to this Feuerbachian challenge because Feuerbach, in other places, challenges the beliefs of Eddy. Feuerbach's position that an existing unknowable God is indistinguishable from

\footnotetext{
${ }^{92}$ John Hick, "Religious Pluralism and the Divine: A Response to Paul Eddy," Religious Studies 31 (1995): 419.

${ }^{93}$ Ludwig Feuerbach, The Essence of Christianity (Buffalo: Prometheus, 1989) 15.
} 
the non-existence of God is a challenge separate from his position that God is simply a human projection.

While Eddy is astute in applying this critique to the philosophy of Hick, he surprisingly misses an even stronger Feuerbachian challenge that applies directly to Hick. While Feuerbach is critical of the position that God is completely unknowable, he is even more critical of distinguishing between God an sich and God as God appears to human consciousness. "But this distinction between what God is in himself, and what he is for me destroys the peace of religion, and is besides in itself an unfounded and untenable distinction. I cannot know whether God is something else in himself or for himself than he is for me; what he is to me is to me all that he is." sich and God as he appears requires a transcendental point of view which is in actuality impossible. I can distinguish between an object as it is in itself and as it appears "only where an object can really appear otherwise to me, not where it appears to me such as the absolute measure of my nature determines it to appear - such as it must appear to me."95

Feuerbach not only maintains the distinction that Hick is trying to make is untenable and unfounded, but also that it is essentially irreligious.

To every religion the gods of other religions are only notions concerning God, but its own conception of God is to it God himself, the true God God as he is in himself. Religion is satisfied only with a complete Deity, a God without reservation; it will not have a mere phantasm of God; it demands God himself. ${ }^{96}$

\footnotetext{
${ }^{94}$ Feuerbach, 16.

${ }^{95}$ Feuerbach, 16.

${ }^{96}$ Feuerbach, 16-17.
} 
This begins to raise the question of the practicality of Hick's hypothesis in the various religious traditions, a question which will be returned to later.

In An Interpretation of Religion, Hick addresses the thought of Feuerbach and other philosophers who have offered positive, non-realist interpretations of religion. But he only critiques their non-realist application of religious language. He rejects the Feuerbachian trade of preserving a certain value of God-talk by showing that it refers to human ideals. While he critiques Feuerbach's positive work, he does not respond to Feuerbach's text that can easily be applied as a critique of the pluralistic hypothesis. 


\section{Chapter 4}

\section{My Response}

Before responding to John Hick's pluralistic hypothesis and the critiques presented, it will be helpful to begin by briefly restating the factors that have brought Hick to his position. As was shown through the dialogue with Alston, Hick places great importance on religious experience for establishing the rationality of religious beliefs for those that have religious experiences. It is, for Hick, the essential element in justifying religious beliefs, for "Persons, if such there be, who never experience religiously in any degree whatever cannot have the same justification for belief." ${ }^{\prime 97}$

But Hick also distinguishes between the strong, vivid religious experiences of the mahatmas and the religious experiences of the ordinary believer. Given the intensity of the reported experiences of the mahatmas, it would actually be irrational for the mahatmas not to trust this experience. ${ }^{98}$ But it seems that the ordinary believer always has a choice to make. This choice lies in how to interpret the religiously ambiguous universe. "Religious belief does not properly depend upon inference from evidences discovered in nature. . but upon unconsciously interpreting the impacts of the environment in such a way that it is

\footnotetext{
${ }^{97}$ Hick, An Interpretation of Religion 221.

${ }^{98}$ Hick, An Interpretation of Religion 216.
} 
consciously experienced as having the kind of meaning articulated in religious experience. In interpreting in this way the believer is making a basic cognitive choice. .."99 While I have trouble understanding exactly how something that occurs unconsciously (in this case the act of interpreting the universe) can be called a choice, it nevertheless seems that, according to Hick, the way one decides to interpret the world will affect the experience one has. These religious experiences, although maybe not vivid or even memorable, "[make] it both possible and reasonable to be so impressed by the reports of the mahatmas that one's own experiences are supported by their much more massive awareness of the transcendent." 100

At this point, Hick and I are in broad agreement. I agree that experience plays a key role in the process of beliefs gaining the status of 'justified'. We all experience the external world and are thus justified in believing in its existence unless sufficient contrary evidence can be obtained. Likewise, those who experience life as being lived in the unseen presence of God or a transcendental Being are justified in believing in the existence of God unless sufficient contrary evidence can be obtained. I also am in agreement with his argument for the religious ambiguity of the universe; or in other words, I agree that sufficient contrary evidence concerning the existence of Brahman/God/Allah/etc. has not been (and possibly could not be) obtained.

However, all this leads Hick to ask the following question: "If the different kinds of religious experience justify people in holding the incompatible sets of

\footnotetext{
${ }^{99}$ Hick, An Interpretation of Religion 210.

${ }^{100}$ Hick, An Interpretaion of Religion 223.
} 
beliefs developed within the different traditions, has not our justification for religious belief thereby undermined itself? Does it not offer an equal justification for the acceptance of a number of mutually contradictory propositions?"101 As we saw in the Alston debate, Hick argues that the notion of 'one, true religion' does undermine the justification of religious belief, hence the need for his pluralistic hypothesis.

My critique of Hick will be two-fold. First, I will show that the argument Hick gives for the need of his pluralistic hypothesis rests on a false premise. Secondly, I will argue that even if I am wrong about this and the premise is true, then Hick will be forced to thoroughly change his entire hypothesis. Thus, I will argue that Hick either has to come up with a new argument for the need of his hypothesis or change the hypothesis itself.

One reason for the invalidity of Hick's argument concerning the need for his hypothesis is that Hick does not properly distinguish between the concepts of justification and truth. In their debate, Hick critiqued Alston because Alston's proposition that 'it is rational to base beliefs on religious experience' and his assumption that 'there is at most one true religion' were contradictory because 'if only one of the many belief-systems based upon religious experience can be true, it follows that religious experience generally produces false beliefs, and that it is thus a generally unreliable basis for belief formation." 102 However, if there is only one true religion, then religious experience may generally produce false beliefs (for that matter, sense experience may generally produce false beliefs),

\footnotetext{
${ }^{101}$ Hick, An Interpretation of Religion 228.

${ }^{102}$ Hick, Dialogues in the Philosophy of Religion 26.
} 
but it does not generally produce unjustified beliefs. Given that we are epistemically cut off from 'truth', it is only justification that concerns us when forming beliefs.

A simplified version of Hick's argument for the need of his pluralistic hypothesis can be stated as follows:

1) Person $A$ is justified in holding the belief that there is a personal, loving God present in the world if this belief is based upon religious experience and there is no strong evidence to refute this belief.

2) Likewise person $B$ is justified in believing that that reality is non-dual if this belief is based upon religious experience and there is no strong evidence to refute this belief

3) It seems, then, that A and B are both justified in believing contradictory things.

4) Given (3), it is implausible that all religious experience is illusion except one's own.

5) Hence the Pluralistic Hypothesis which explains how each of the major traditions, which each give evidence to show that they are valid responses to the Real via their moral fruits, are in equal relation to the Ultimate Reality. ${ }^{103}$

However, it seems that step 4 is an unwarranted move. If $A$ recognized that $B$ is just as justified in believing something contradictory to what she is justified in believing, she would not have to rationally admit that it is implausible that B's contradictory beliefs do not correspond to reality. Keith Ward, in his article

${ }^{103}$ Keith Ward, "Truth and the Diversity of Religions," Religious Studies 26 (1990): 12. 
entitled "Truth and Religious Diversity" also notices this when he write, "Hick has already argued that both atheists and theists can be rationally justified in adopting the views of the world they adopt, given the ambiguous nature of that world. But it does not follow that each must accept the other's view as equally true.."104

My point can be made clear by way of example from sense experience. If I look into the sky and see an object that appears to me to be a bird, then I am justified in believing that it is a bird provided there is not other evidence that strongly suggest that this is not the case. If my neighbor Julie looks up into the sky and observes the same object but it appears to her to be an airplane, she is justified in believing that it is an airplane providing that no countervailing evidence is available. If I notice that Julie is justified in believing that it is a plane, and if $I$ also recognize that it cannot be both a bird and a plane, I do not have to admit that it is implausible that she is in some sense deluded. Actually, given my justification for believing that it is a bird I would be internally justified in believing that Julie is deluded. That is, given that I am 1) justified in believing that the object is a bird, and that I am 2) justified in believing that Julie is justified in believing that it is an airplane, I am therefore 3) justified in believing that Julie is deluded.

However, this does not mean that Julie is in fact deluded, for the object could be a plane and, thus, I would be the one who is deluded. So, the fact that two people can be equally justified from the same type of experience in believing

${ }^{104}$ Ward, 12-13. 
two contradictory propositions, does not require a belief that the two propositions are equally true.

Perhaps Hick could counter Ward's point by pointing out that the atheist and the theist are not in the same relation to one another as the theist and the absolutist because the theist and the absolutist have the same type of experience (religious experience) whereas the theist forms certain beliefs on a type of experience that the atheist does not have. The question of reliability is not as prevalent concerning sense experience because there is generally broad agreement as to the nature of the experience. Great diversity of opinion does not occur with beliefs formed from sense experience, so questions of its reliability are not as acute as with religious experience. Hick may similarly counter my point by arguing that contradictory reports from sense experience are the exception rather than the rule so we do not have to view sense experience as an unreliable basis for belief formation, for it is at least possible that it generally produces true beliefs. However, religious experience does, as a rule, produce contradictory propositions, so it seems that it is impossible for religious experience to generally produce true beliefs, unless we understand this in another way, i.e. the pluralistic hypothesis.

But Hick's argument for the need of his hypothesis faces further difficulties in that it rests upon a heavily implicit and questionable assumption. Hick adheres to an externalist/reliabilist theory of justification. "Most externalist theories of the adequacy of grounds can be represented as reliabilist theories of various kinds, the central idea of which (to put it now more carefully) is that grounds of a 
particular belief are adequate if (and only if) the particular. . . process of belief formation belongs to a reliable kind. . . A process is more reliable, the greater the proportion of true beliefs it produces."105

Hick shows this to be his epistemological stance in the dialogue with Alston. He argues that if only one religion is true then religious experience is an unreliable basis for forming beliefs. ${ }^{106}$ This then leads him to the conclusion that the 'one true religion' belief is 'fatal to Alston's thesis that it is . . . rational to base beliefs on religious experience." ${ }^{107}$ For Hick, if there is at most only one true religion, then religious experience is an unreliable basis for belief formation. If religious experience is an unreliable basis for belief formation, then it cannot adequately justify religious beliefs. Note that Hick does not admit the first premise and, therefore, does not have to admit the conclusion. But he argues that since Alston does admit the first premise, he must admit the conclusions. But implicit in Hick's argument is the assumption that in order for a belief to be justified, it must be arrived at by means of a reliable (or truth conducive) basis.

However, this assumption is questioned by more internalist theories of justification. Internalist theories espouse the idea that the justification of a belief is necessarily internal to the believer. ${ }^{108}$ "The internalist insists that it is only the subject's beliefs about whether a process is or is not reliable that are relevant to the justification of a resulting belief, whereas for the externalist it is only the fact

\footnotetext{
${ }^{105}$ Richard Swinburn, Epistemic Justification (Oxford: Clarendon, 2001) 13.

${ }^{106}$ Hick, Dialogues in the Philosophy of Religion 26.

${ }^{107}$ Hick, Dialogues in the Philosophy of Religion 26.

${ }^{108}$ Swinburne, 9.
} 
that the process is or is not reliable - whether or not the subject believes that that is relevant." 109

While it would be entirely outside the scope of this paper to try and settle the debate that continues between externalist/reliabilist and internalist theories of justification in favor of the latter, $I$ can at least point out some of the major objections to the former and show how this applies to Hick's epistemological position. ${ }^{110}$ To begin with, it is important to note that "reliabilism does not require that the believer in question have any sort of cognitive access to the fact that the belief producing process is in this way reliable in order for his or her belief to be justified. All that matters for justification is that the process in question is in fact reliable"111 independent of what the believer happens to think about the process.

With this basic tenet in mind, consider a group of people who live in a world that is controlled by a malicious demon of the sort imagined by Descartes. This malicious demon controls all of the sensory and intuitive experiences of the people, causing them to believe that a material world much like the one we experience exists, when in fact no material exists. These people are just as rigorous in their science and philosophy as we are, yet they form the false belief that the external world that they experience exists and form many other false beliefs based upon the deceptive appearance.

Intuitively, it seems that the people of this world are justified in believing in the beliefs at which they arrive. For "their epistemic situation may, from their own

\footnotetext{
${ }^{109}$ Swinburne, 21.

${ }^{110}$ I am entirely indebted to Laurence Bonjour's article "Internalism and Externalism," The Oxford Handbook of Epistemology, ed. Paul K. Moser (Oxford, New York: Oxford UP, 2002) 234-263, as the source of the objections to externalism.

${ }^{111}$ Bonjour, 244-45.
} 
subjective standpoints, well be entirely indiscernible from or even superior to our own, so that if we are confident that our own beliefs are frequently justified, we should seeming be equally confident that theirs are." ${ }^{112}$ But this is just what the reliabilist denies. In light of this example, it seems that if the reliabilist theory of justification is correct, it would be impossible to distinguish with certainty justified beliefs from unjustified beliefs. Moreover, it seems to me that any claim that a certain process is or is not reliable is itself a belief, which in order to be justified by the reliabilist standard must also be formed on the basis of a reliable process. Unless the reliabilists can provide an ultimate ground, this is the beginning of an infinite regress. Moreover, it is generally held that while externalist theories regarding knowledge are plausible, externalist theories regarding justification are much less so. "The idea that knowledge is externally grounded and justification internally grounded would help to explain why reliability theories are. . . as plausible as they are for knowledge, yet much less plausible for justification." ${ }^{113}$

Still, the debate over externalism and internalism is one that continues today and there are also many objections to internalist theories of justification. But even if externalism and Hick's basic point concerning the need for his hypothesis are correct, then his hypothesis and even his entire definition of the problem are much too limited in scope. For if we think about religion as a 'family concept' so that it would include Marxism, Humanism, etc. then we would have to conclude that given the diversity of opinions that are based on experience, experience generally produces false beliefs unless we can come up with a

\footnotetext{
${ }^{112}$ Bonjour, 247.

${ }^{113}$ Robert Audi, Belief, Justification, and Knowledge (Belmont: Wadsworth, 1988) 115.
} 
hypothesis that sees all these ideologies as equally true. For instance, as Hick notes, certain people interpret the world in a completely naturalistic way and thus form the belief that only material exists. They may also, based upon experiences of economic injustice and oppression, come to adhere to Marxism. Or, based on their interpretation of their experiences, people may come to be Humanists, extreme idealists, pantheists, etc.

Taken to a more general level, Hick's own critique of Alston can be used against him. It is clear from his writings that Hick is a dualist and believes that materialism and idealism are false. However, Hick also maintains that given the ambiguous nature of the universe others can justifiably believe in materialism or idealism if these beliefs are based on experience. But Hick's assumption that only one of these can be correct is fatal to his empiricist position that it is rational to base beliefs on experience. For if only one of these can be true it follows that experience generally produces false beliefs, and that it is an unreliable basis for belief formation. ${ }^{114}$ Hick focuses our attention on transcendental religions and then gives his argument that there is a problem of religious diversity that needs to be addressed. However, if this is in fact a problem it is much wider than religious diversity and is rather a problem of world-view diversity.

Keith Ward, in his critique of Hick, also notices something similar, but does not focus upon it to question whether there is in fact a problem of religious diversity. He states that:

"What [Hick] is doing is to pick out one class of religious beliefs, or one set of religious phenomena which can be defined in terms of belief in a transcendent salvific reality. There is nothing wrong with that; but it should

\footnotetext{
${ }^{114}$ See Hick's parallel argument in Dialogues in the Philosophy of Religion, 26.
} 
be noted that it picks out one area of agreement in truth-claims by definition. Faiths which lack that central belief are not going to be counted; conversely, faiths which are counted are assured a minimal degree of agreement to begin with. . . But, so far, this is not really pluralism (the acceptance of very different beliefs as equally valid); it is exclusivism at a relatively abstract and general level (those are excluded who do not believe in one transcendent salvific reality). ${ }^{115}$

But when this observation is made in conjunction with the argument Hick gives for the need for his hypothesis, there does seem to be something wrong with focusing attention on one type of religious belief, for it presents the alleged problem to be much simpler than it actually is.

Thus, if Hick wants to continue to maintain that the argument he gives for the need of his hypothesis is correct, then he needs to change his entire hypothesis because it is much too limited in scope. His hypothesis would have to explain how all or most rational world views can be viewed as being equally true despite their differences, not just how all of the major post-axial religious faiths can be seen as equally true. Conversely, if Hick wants to preserve his hypothesis the way it is, he needs to give a different argument for the need of the hypothesis. He needs to argue for what he simply assumes in the dialogue with Alston, namely externalism/reliabilism; but at the same time argue that this epistemological position somehow only applies to the beliefs of the religions he is considering at not to beliefs in general. For if externalism/reliabilism holds for all beliefs, then, given the diversity and mutual incompatibility of beliefs based on experience in general, experience cannot be a reliable method in justifying beliefs.

${ }^{115}$ Ward, 3. 
In the absence of any new argument for the need of his hypothesis, I will now argue for what I think does follow from Hick's observation that people can be equally justified in believing contradictory religious propositions. If I recognize that other people are equally justified in believing religious propositions that are contradictory to my own, it seems that I must admit that my own religious views are fallible and uncertain. This observation does not need to force me to religious skepticism, for "just because it is possible for me to go wrong, it does not follow that I can never go right." ${ }^{116}$ And while the position of religious falliblism hedges those who hold it from religious skepticism on the one end, it has the added advantage of hedging those who hold it from religious dogmatism on the other. For while religious falliblism requires the observation that I could be wrong, it also requires the observation that people from traditions different from my own could be right in many important respects. Thus, it keeps my religious beliefs open to constant revision. Moreover, on this observation, my proposal of religious falliblism seems to be a "moderate, rational, balanced, Anglican-style middle way"117 of the kind of which Hick is so fond.

Hick seems to be concerned with opening up space for religious dialogue and is interested to "move beyond the static situation of rival absolutisms." ${ }^{118}$ But if this is a driving force for Hick in the creation of his hypothesis, then one should notice that religious falliblism offers an alternative to Hick's way of accomplishing this goal. For if I recognize that I could be wrong and others could be right, it

\footnotetext{
${ }^{116}$ Kwasi Wiredu, Cultural Universals and Particulars: An African Perspective (Bloomington: Indiana UP, 1996) 140.

${ }^{117}$ Hick, "Religious Pluralism and the Divine: A Response to Paul Eddy" 420.

${ }^{118}$ Hick, Disputed Questions in Theology and the Philosophy of Religion 154.
} 
becomes advantageous for me to listen to those with opposing religious views. And while it would not be rational for me to accept religious propositions that completely clash with my experience, I am kept safe from the 'static situation' Hick mentions because religious fallibilism keeps my religious beliefs open to constant revision. Moreover, Hick's pluralistic hypothesis has just as much potential to be held dogmatically as any other religious system. 


\section{Conclusion}

Throughout this study of John Hick and religious pluralism, it has been shown how Hick's insistence on the importance of religious experience in justifying religious beliefs leads him to argue that there is a problem of religious diversity that can only be successfully solved by his pluralistic hypothesis. The two issues of the rationality of religious beliefs and religious pluralism are for Hick inextricably linked, for the way he argues for the rationality of religious beliefs pushes him to his religious pluralism. However, I have argued that one can agree with the way Hick argues for the rationality of religious belief without maintaining that there is a need for a pluralistic hypothesis. This can be done by adopting an internalist theory of justification and by always keeping the distinction between justification and truth sharp. In so doing, we do not have to follow Hick down the road that Heim, Eddy, Feurerbach and others have shown is so riddled with problems; but we must adopt an attitude of religious falliblism. By doing this we avoid the extremes of skepticism and dogmatism and keep the line of religious communication open. Moreover, we preserve an attitude of humility that is advocated by all of the great religious traditions. 


\section{References}

Alston, William. "Section 2(i)(b)." Dialogues in the Philosophy of Religion. Ed. John Hick. New York: Palgrave, 2001. 37-8, 42-52.

Audi, Robert. Belief, Justification, and Knowledge. Belmont: Wadsworth, 1988.

Bonjour, Laurence. "Internalism and Externalism." The Oxford Handbook of Epistemology. Ed. Paul K. Moser. Oxford, New York: Oxford UP, 2002. 234-263.

Eddy, Paul R. "Religious Pluralism and the Divine: Another Look At John Hick's Neo-Kantian Proposal." Religious Studies 30 (1994): 467-78.

Feuerbach, Ludwig. The Essence of Christianity. Trans. George Eliot. Buffalo: Prometheus, 1989.

Gillis, Charles. "An Interpretation of An Interpretation of Religion." Problems in the Philosophy of Religion: Critical Studies of the Work of John Hick. Ed. Harold Hewitt, jr. New York: St. Martin's, 1991.

Heim, Mark S. "The Pluralistic Hypothesis, Realism, and Post-Eschatology. Religious Studies 28 (1992). 207-19.

Hick, John, ed. Dialogues in the Philosophy of Religion. New York: Palgrave, 2001.

--.. Disputed Questions in Theology and the Philosophy of Religion. New Haven: Yale UP, 1993.

---. An Interpretation of Religion: Human Responses to the Transcendent. New Haven: Yale UP, 1989.

---. "Eschatological Verification Reconsidered." Religious Studies. 13 (1977): 189-202.

---. "Religious Pluralism and the Divine: A Response to Paul Eddy." Religious Studies. 31 (1995): 417-20. 
Swinburne, Richard. Epistemic Justification. Oxford: Clarendon, 2001.

Ward, Keith. "Truth and the Diversity of Religions." Religious Studies 26 (1990): $1-18$.

Wiredu, Kwasi. Cultural Universals and Particulars: An African Perspective. Bloomington: Indiana UP, 1996. 


\section{Curriculum Vitae}

Name:

John K. Dryden, Jr.

Address: $\quad 6900$ Sprig-Leaf Cr.

Louisville, KY 40241

DOB: $\quad$ Louisville, KY - July 25, 1976

Education: B.A., Philosophy University of Louisville 1996-2000

Awards: Nomination for Mortar Board National Honor Society, 2000

Professional

Societies: American Philosophy Association - member 